\title{
SEDIMENT GEOCHEMISTRY OF A MEROMICTIC COASTAL LAGOON, “ES CIBOLLAR” (MAJORCA, SPAIN)
}

\author{
P. López; X. Lluch. \\ Dep. Ecology, University of Barcelona, Avgda Diagonal 645, Barcelona 08028, SPAIN
}

\begin{abstract}
The concentrations of major and nutrient elements, (AI, Fe, Si, K, Ti, Ca, Mg, Mn, P, carbonate carbon, organic carbon, and $\mathrm{N}$ ) in the sediments of a small, meromictic coastal lagoon (Es Cibollar, Majorca Island) were measured along a vertical profile in two core samples collected respectively two and eight months after a mixing event. The geochemical composition was studied through a multivariate statistical approach in order to identify the probable main mineral phases as well as the main processes controlling sediment composition in the lagoon. The results showed the presence of three main mineral fractions: the carbonate phase (magnesium calcite) was the most abundant component ( $>70 \%$ in dry weight) and presented little vertical variation, whereas the organic fraction and the clay fraction varied markedly with depth. Samples collected after two and eight months of anoxia only presented clear differences for phosphorus, which was associated with iron after two months of anoxia and with organic carbon after eight months. A principal component analysis of the bulk analysis data extracted two principal components that explained respectively $58.2 \%$ and $23.7 \%$ of total variance. The first factor with high positive loadings for $\mathrm{AI}, \mathrm{Fe}, \mathrm{Ti}, \mathrm{K}$ and $\mathrm{Si}$ and high negative loadings for $\mathrm{Ca}, \mathrm{Mg}$ and carbonate is considered to be associated with the relative contribution of allochthonous and autochthonous matter. The second factor with positive loadings for organic carbon, N, P and $\mathrm{Mn}$ has been interpreted as the balance between organic matter accumulation and decomposition.
\end{abstract}

Key words: sediment composition, bulk analysis, principal components, anoxia, decomposition

\section{RESUMEN}

Se han determinado las concentracionesde los elementos mayoritariosy nutrientes (Al, Fe, $\mathrm{Si}, \mathrm{K}, \mathrm{Ti}, \mathrm{Ca}, \mathrm{Mg}, \mathrm{Mn}, \mathrm{P}$, carbono en forma de carbonato, carbono orgánico y nitrdgeno total) a lo largo de un perfil vertical de sedimento de una laguna costera meromictica (Es Cibollar, Mallorca). Los cilindros de sedimento se recogieron tras dos y ocho meses respectivamente de un corto episodio de mezcla total. Para poder identificar lasprincipales fases mineralesy los procesos que controlan la composicidn del sedimento en la laguna se ha estudiado la conzposicidn geoquimicu mediante un análisis estadistico multivariante. Los resultudos muestran la presencia de tres fracciones mayoritarias: lafuse carbonatadu (calcita magnésica) es la más abundante ( $70 \%$ del peso seco)presentando una variacidn vertical muy pequeña, mientras que lafruccidn orgánica y lafruccidn arcillosa varian acusadamente en profundidad. Las muestras recogidas tras dos y ocho meses de anoxia solo se diferencian claramente en la concentración de fósforo, que aparece asociado a hierro tras dos meses de anoxia y asociado al carbono orgánico tras ocho meses de anoxia. El análisis de componentesprincipales efectuado sobre la composicidn elemental extrae dos componentes principales que explican respectivamente el 58.2\% y e123.7 de la varianza total. El primer factor, que esta positivamente relacionado con Al, $\mathrm{Fe}, \mathrm{Ti}, \mathrm{K}$ y Si y negativamente relacionado con $\mathrm{Ca}, \mathrm{Mg}$ y carbono en forma de carbonato, se considera asociado a la contribucidn relutiva de materiales alóctonos y autóctonos. El segundofactol; determinadopor carbono orgánico, nitrdgeno total, $P$ y Mn se interpreta como el balance entre acumulacidny descomposicidn de la materia orgánica.

Palabras clave: composición del sedimento, componentes principales, anoxia, descomposición.

\section{INTRODUCTION}

The study of the chemical composition of lake sediments helps to elucidate the many processes occurring within the total lake system including its groundwater drainage basin. Sediments are the depositional site of mineral and organic matter transported from the catchment area, as well as matter that forms and settles from within the water body. But sediments also play an active role in regulating cycles of nutrient elements and trace metals, this role depending on chemical and mineral composition, biological activity and redox conditions, which in turn, are closely rela- 
ted. Thus, lake sediments integrate the natural weathering processes of the catchment area, the biotic and abiotic transformations in the lake itself and the human activities that affect the water body (Forstner, 1989).

Multivariate statistical treatment of bulk analysis data has been widely used to study trace metal characterization (Belmans et al., 1993) and behaviour (Van Alsenoy et al., 1993; Voutsinou-Taliadouri \& Varnavas, 1995) and also to study changes in sediment composition over time (Principi et al., 1994). However, to interpret geochemical data from bulk techniques, two important aspects must be considered: firstly, bulk analyses do not take into account that sediments are a complex mixture of discrete mineral phases and organic compounds (Jones \& Bowser, 1978); secondly, the constant sum effect due to the expression of data as part of a whole (percentage or part per million) can produce misleading results when correlations between elements are calculated (Aitchinson, 1986; Rollinson, 1993).

Aitchinson (1986) proposes that compositional data should be expressed as the covariance of log-ratios of the variables rather than the raw percentages, in order to avoid the problems associated with the constant sum effect. From the covariance matrix, associations between elements that coexist in a same mineral can be observed, and mineral phases can be identified (Aitchinson, 1986; Rollinson, 1993).

The geochemical composition of the sediments of Es Cibollar, a small meromictic coastal lagoon was studied within a wider project performed on the Albufera of Majorca/Alcudia Bay system. The aims of the study presented here were:

1) to asses the main relationships between the geochemical variables in a meromictic coastal system and their modifications after a long period of anoxia.

2) to identify the main processes that control the sediment composition in this lagoon, through a multivariate statistical approach.

\section{MATERIAL AND METHODS}

\section{Study area}

The Es Cibollar lagoon is a pond located in the northeast of the Albufera of Alcudia (Majorca island), a marsh area with several ponds connected through an extense system of channels (MartinezTaberner et al., 1990). It was formed by dredging of a shallower pond about 30 years ago. The lagoon has a dual connection with the sea,'either though another lagoon and directly through a canal. The surface area is $0.04 \mathrm{Km}^{2}$, the volume about $130 \cdot 10^{3} \mathrm{~m}^{3}$, the mean depth is $3.3 \mathrm{~m}$ and the maximum depth $8.25 \mathrm{~m}$. Previous studies (Moyà et al., 1987) showed that it remains stratified throughout the year because of a strong salinity gradient due to seawater input by depth. In very dry and hot summers, the pycnocline disappears because evaporation causes a substantial increase in the salinity of surface water. Nevertheless, the mixing period is short and the water column become stratified rapidly.

Sediment was sampled in winter (December 1992), two months after a short mixing event that allowed to a oxygenation of the sediment, and summer (July 1993), after eight months of permanent anoxia.

\section{Methods}

The cores obtained with a modified Eckmangrab were immediately sliced into $1 \mathrm{~cm}$ sections and $\mathrm{pH}$ and $\mathrm{E}$, were measured. Redox potentials were read with a platinum electrode with a calomel electrode as reference. The electrodes were allowed to equilibrate for approximately 5 minutes at each depth. Potentials are reported relative to a standard $\mathrm{H}_{2} / \mathrm{H}^{+}$. pH was measured with a Ross elecrode (Orion). The $1 \mathrm{~cm}$-sections were centrifuged (15 $\mathrm{min}, 4500 \mathrm{rpm})$ and the precipitate was dried at $110^{\circ} \mathrm{C}$ and, after homogenization it was divided into three aliquots. One was used to determine major components of the solid phase through X-ray fluorescence analysis (Musikas \& Vantighem, 1977). Another was used to determine total carbon and nitrogen with 
a Carlo-Erba analyzer, and the last was acidified with $\mathrm{HCl}$ to remove carbonates and then analyzed for organic carbon. Following Jones \& Bowser (1978) and Principi et al. (1994) the analyses were performed without separating granulometric classes or chemical fractions. Statistical treatment of data was performed with the SPSS program.

\section{RESULTS AND DISCUSSION}

\section{pH and $E$,}

The sediments of the Cibollar lagoon were extremely fluid on their surface, with a porosity near 1 at the first centimeter (Fig. 1). In both seasons, E was negative up to the surface; in winter, E, decreased sharply (around $30 \mathrm{mV}$ ) in the top 5 $\mathrm{cm}$ and below this depth its diminution was less pronounced (around $20 \mathrm{mV}$ in $10 \mathrm{~cm}$ ). In summer, E, showed a vertical profile fairly homogeneous, around $-200 \mathrm{mV}$ (Fig. 1). $\mathrm{pH}$ presented a significant decrease from 0 to $4 \mathrm{~cm}$ in winter (Fig. 1), stabilizing around 7.1 below this depth. In summer it was rather homogeneous, with values near 7.0, along the vertical profile.

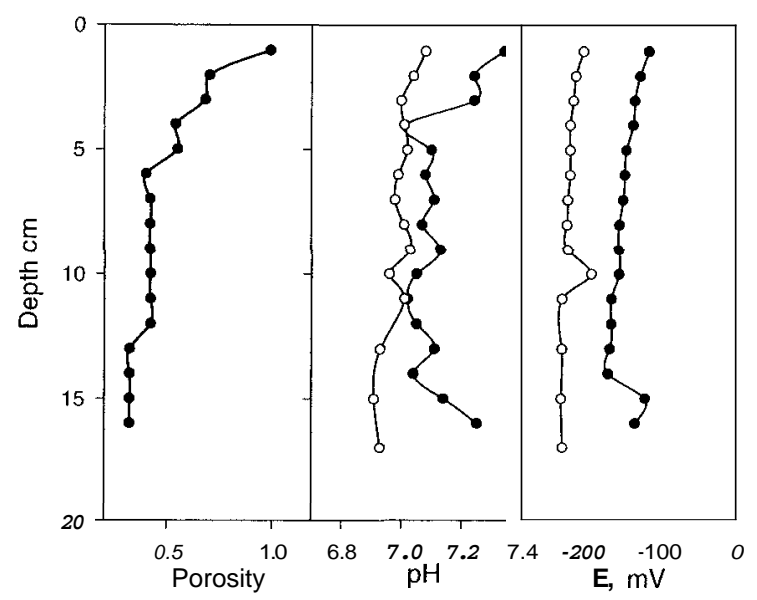

Figure 1. Vertical profiles for porosity, $\mathrm{pH}$ and $\mathrm{E}$, in the sediments of Es Cibollar lagoon. Full circles: December data; empty circles: July data. Perfil vertical de porosidad, $\mathrm{pH}$ y E, en el sedimento de la laguna de Es Cibollar. Círculos negros: datos de Diciembre. Círculos blancos: datos de Julio.
The values of $\mathrm{E}$, and $\mathrm{pH}$ observed at Cibollar lagoon are characteristic of anoxic and highly reducing sediments, suggesting sulphate reduction as the main respiratory process in July. The $\mathrm{pH}$ of this kind of sediments is affected by a complex set of reactions remaining with rather narrow limits of 6.9-7.2 (Striebel et al., 1991). The pore water composition of the Cibollar lagoon also agrees with sulphate-reduction occurring as main decomposition pathway in summer (Lopez et al., in press).

\section{Geochemical Composition}

The elemental composition of sediments of the Es Cibollar lagoon is presented in Table 1 and figures 2 and 3 . Table 1 gives mean concentrations, standard deviations and coefficient of variation of the elements analyzed in the cores collected in December (C1), and July (C2) separately and for the whole set of data. Figures 2 and 3 show the vertical variation of major elements on both cores.

Calcium and carbonate were the most abundant components of the sediment, their sum accounting for more than $73 \%$ of dry weight. These components showed little variation with depth (Fig. 3) and differences between cores were also very small, although values in $\mathrm{C} 2$ were always slightly higher except at $12 / 13 \mathrm{~cm}$. Magnesium (Fig. 2) was the second cation in abundance, presenting a pattern of variation very close to those of calcium and carbonate.

Aluminium, iron, titanium, silicon and potassium presented low concentrations, as it could be expected from the calcareous nature of the sediments. These elements showed more vertical variation (CV around $25 \%$ ), with a clear increase in their concentrations with depth from $10 \mathrm{~cm}$. Differences between cores were less apparent, but, as a whole, concentrations were lower in C2 (Fig. 2) .

The concentrations of organic carbon $\left(\mathrm{C}_{\mathrm{org}}\right)$ and total nitrogen $\left(\mathrm{N}_{\text {tot }}\right)$ were moderate, with a maximum of $3.10 \%$ for $\mathrm{C}_{\text {org }}$ and $0.50 \%$ for $\mathrm{N}_{\text {tot }}$. These values were lower than those reported for other anoxic coastal systems (Bonanni et al., 1992) and for eutrophic lake sediments (Principi 
Table 1. Mean, standard deviation and coefficient of variation $(\mathrm{SD} / * 100 \mathrm{Mean})$ of the analyzed elements in both cores separately and in the whole data set. Media, desviacidn estandar y coeficiente de variación (SD/IOOMedia) de los elementos analizados en cores separados ypara el total de los datos ohtenidos.

\begin{tabular}{|c|c|c|c|c|c|c|c|c|c|}
\hline & \multicolumn{3}{|c|}{ C1 } & \multicolumn{3}{|c|}{$\mathbf{c 2}$} & \multicolumn{3}{|c|}{ GLOBAL } \\
\hline & Mean & S.D & C.V & Mean & S.D. & C.V. & Mean & S.D. & C.V. \\
\hline $\begin{array}{l}\text { Al } \\
\text { mmol.g-1 }\end{array}$ & 0.48 & 0.17 & 34.86 & 0.42 & 0.17 & 39.69 & 0.45 & 0.17 & 37.65 \\
\hline $\begin{array}{l}\mathrm{Fe} \\
\text { mmol.g }{ }^{-1}\end{array}$ & 0.14 & 0.03 & 21.89 & 0.13 & 0.03 & 25.35 & 0.13 & 0.03 & 23.87 \\
\hline $\begin{array}{l}\mathrm{Ti} \\
\mu \text { mol.g }{ }^{-1}\end{array}$ & 15.59 & 4.28 & 27.47 & 13.35 & 4.66 & 34.87 & 14.54 & 4.60 & 31.64 \\
\hline $\begin{array}{l}\mathrm{Si} \\
\mathrm{mmol} . \mathrm{g}^{-1}\end{array}$ & 1.97 & 0.28 & 14.00 & 1.88 & 0.29 & 15.41 & 1.93 & 0.29 & 14.82 \\
\hline $\begin{array}{l}\mathrm{Ca} \\
\mathrm{mmol} . \mathrm{g}^{-1}\end{array}$ & 7.02 & 0.23 & 3.25 & 7.25 & 0.31 & 4.22 & 7.13 & 0.29 & 4.08 \\
\hline $\begin{array}{l}\mathrm{Mg} \\
\text { mmol.g-1 }\end{array}$ & 0.69 & 0.05 & 7.97 & 0.12 & 0.05 & 6.71 & 0.70 & 0.05 & 7.71 \\
\hline $\begin{array}{l}\mathrm{P} \\
\mu \mathrm{mol.g} \mathrm{g}^{-1}\end{array}$ & 24.92 & 12.21 & 49.00 & 15.72 & 3.33 & 21.18 & 20.59 & 10.26 & 49.83 \\
\hline $\begin{array}{l}\mathbf{K} \\
\mu \text { mol.g } \mathbf{g}^{-1}\end{array}$ & 127.8 & 37.2 & 29.1 & 109.1 & 39.6 & 36.3 & 119.0 & 39.5 & 33.2 \\
\hline $\begin{array}{l}\text { Mn } \\
\mu \text { mol.g }\end{array}$ & 4.70 & 2.25 & 47.95 & 3.79 & 1.08 & 28.56 & 4.27 & 1.85 & 43.46 \\
\hline $\begin{array}{l}\mathrm{C} . \mathrm{CO}_{3} \\
\mathrm{mmol} . \mathrm{g}^{-1}\end{array}$ & 7.55 & 0.41 & 5.48 & 7.96 & 0.44 & 5.47 & 7.75 & 0.47 & 6.01 \\
\hline $\begin{array}{l}\text { C.Corg } \\
\text { mmol.g-1 }\end{array}$ & 2.16 & 0.41 & 19.11 & 1.78 & 0.44 & 24.79 & 1.98 & 0.47 & 23.65 \\
\hline $\begin{array}{l}\text { N.Ntot } \\
\text { mmol.g- }\end{array}$ & 0.21 & 0.06 & 30.89 & 0.20 & 0.08 & 39.96 & 0.21 & 0.07 & 35.36 \\
\hline
\end{tabular}

et al., 1994). Both elements decreased with depth (Fig. 3), $\mathrm{N}_{\text {tot }}$ being more variable than $\mathrm{C}_{\mathrm{org}}$. At surface, $\mathrm{C}_{\mathrm{org}}$ and $\mathrm{N}_{\text {tot }}$ were higher in $\mathrm{C} 2$, but below $2 \mathrm{~cm}^{\mathrm{corg}}$ was clearly lower in $\mathrm{C} 2$ and $\mathrm{N}_{\text {tot }}$ presented similar concentrations in both cores.

Phosphorus was the most variable element, mainly in $\mathrm{C} 1$ where the vertical profile was similar to that of aluminum, with a notable increase below $10 \mathrm{~cm}$. In $\mathrm{C} 2$, phosphorus varied with depth as $\mathrm{C}_{\text {org }}$ and $\mathrm{N}_{\text {tot }}$ decreasing from the surface. The mean concentration of phosphorus was of the same order as those reported for other Mediterranean lagoons (Bonanni et al., 1992).
Finally, manganese presented a coefficient of variation of the same order as aluminum (about $28 \%$ ), but its vertical profile was very different from the other components, with the maximum concentrations being found between 6 and $\mathrm{I} 2 \mathrm{~cm}$.

\section{Relationships Between Geochemical Variables}

In order to identify the main relationships between the elements studied, compositional data are expressed as a variation matrix, in which logratio variances are calculated for every variable 
divided by every other variable (Table 2 ) and as a centred log-ratio covariance matrix (i.e. the covariance of each pair of elements expressed as natural logarithms of concentration of each element divided by the geometric mean of all components) (Table 3). High values in the variation matrix identify the pairs of elements that show the greatest variability. In the covariance matrix, high positive values can be interpreted to mean that the elements coexist in the same mineral phase, whereas large negative values tend to confirm the variability indicated in the variation matrix (Rollinson, 1993).

Data from Tables 2 and 3 allow us to distinguish four main groups of elements, that may be identified as different mineral phases.
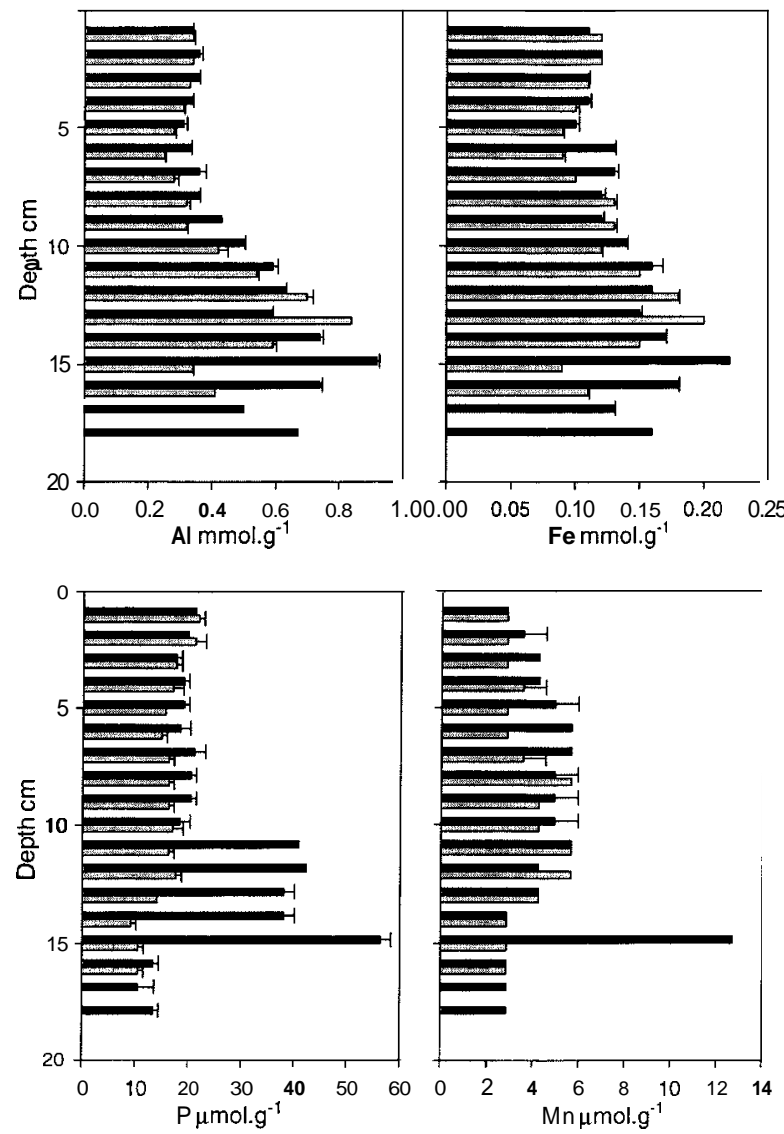
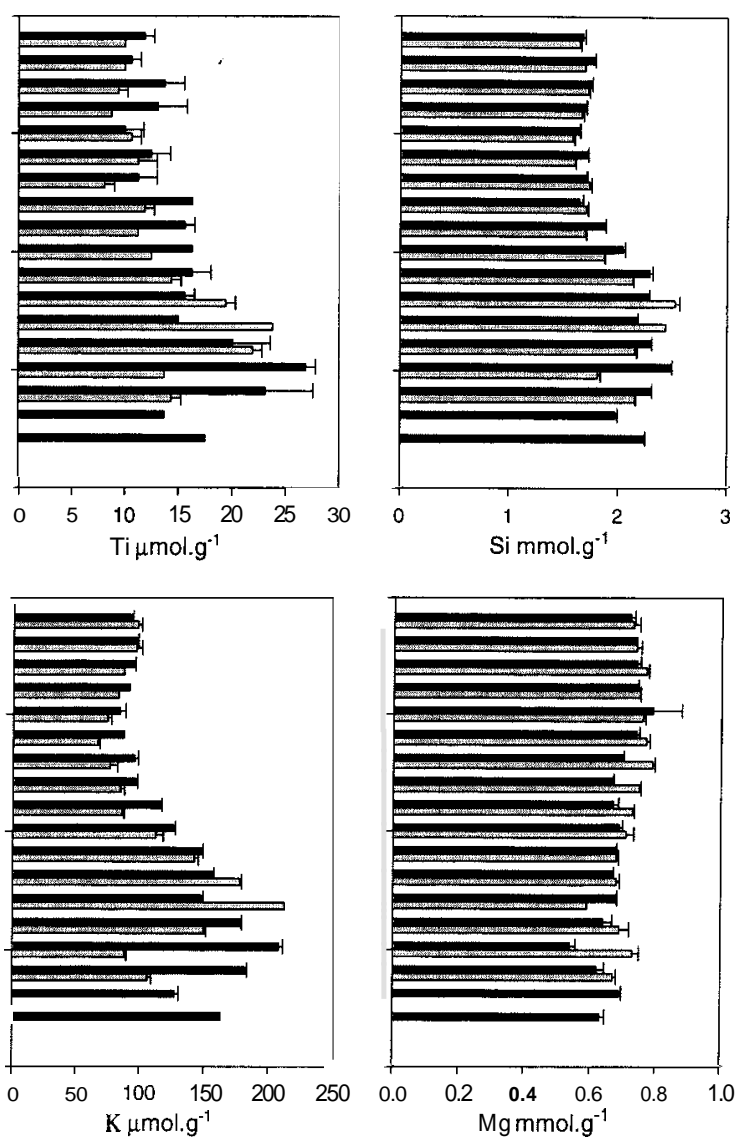

Figure 2. Mean concentrations and standard deviation of the major elements along the vertical profile of sediment in Es Cibollar lagoon. Black bars: December data $(\mathrm{C} 1)$; Grey bars: July data (C2). Concentración media y desviación standard de los elementos mayoritarios a lo largo de un perfil vertical en el sedimento de Es Cibollar. Barras negras: datos de Diciemhre (C1); Burrus grises: datos de Julio (C2). 

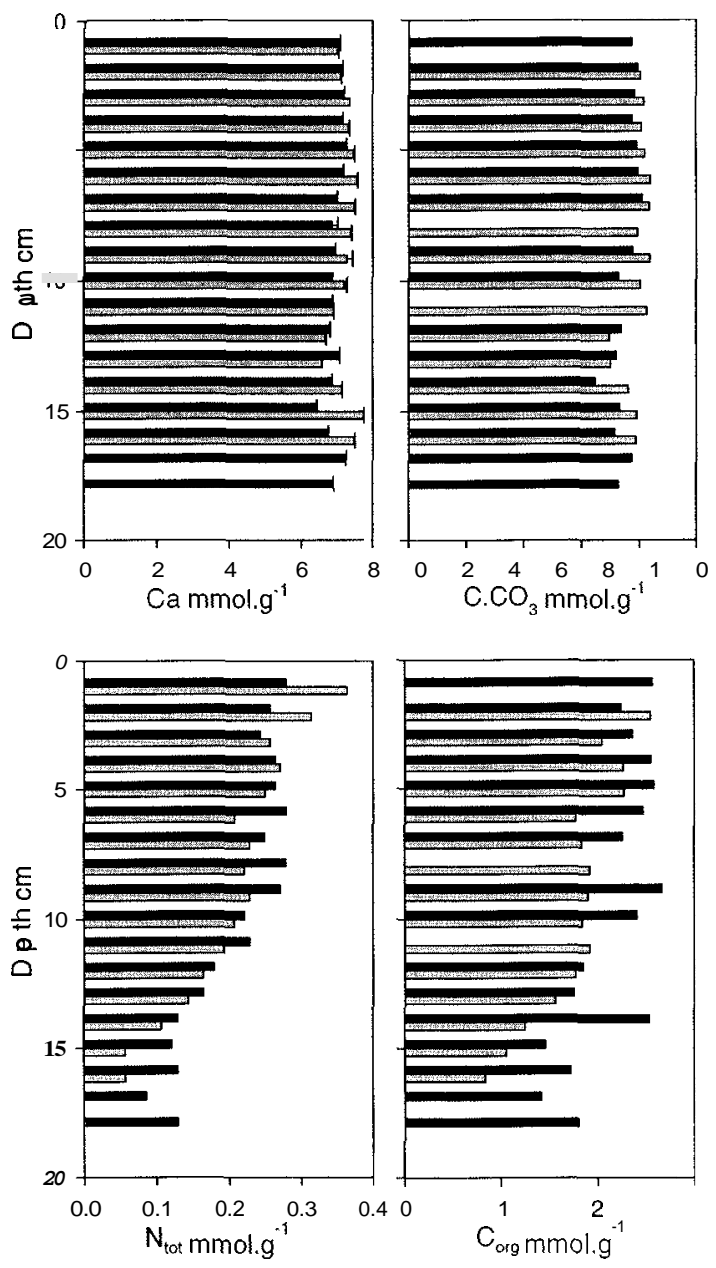

Figure 3. Mean concentrations and standard deviation of calcium, organic carbon, carbonate carbon and nitrogen along the vertical profile of sediment in Es Cibollar lagoon. Values of organic carbon, carbonate carbon and nitrogen are from single data. Black bars: December data $(\mathrm{C} 1)$; Grey bars: July data (C2). Concentración media y desviación standard de calcio, cnrhono orgánico, curbono en forma de carbonato y nitrógeno a lo largo de un perfil vertical en el sedimento de Es Cibollar. Los valores de curbono orgánico, carbono en forma de carbonato y nitrógeno son valores individuales. Barras negras: datos de Diciembrr (CI); Barras grises: datos de Julio (C2).

at $15 / 13 \mathrm{~cm}$ and a maximum (6.5 in $\mathrm{C} 2,5.3$ in C1) at $6 \mathrm{~cm}$.

The second group is formed by $\mathrm{C}_{\text {org }}$ and $\mathrm{N}_{\text {tot }}$. They presented high positive covariance, and very high negative values with the other elements, especially those associated to the clay fraction. The variance of the $\mathrm{C}_{\text {org }} / \mathrm{N}_{\text {tot }}$ ratio was relatively high (although it was lower than the ratios with the other elements), reflecting the increase of the $\mathrm{C}_{\text {org }} / \mathrm{N}_{\text {tot }}$ ratio observed with depth (Fig. 4).

The third group is formed by calcium, carbonate and magnesium and may be associated with the carbonate phase. These elements were constant in their vertical profiles, so covariances were small. Nevertheless, the most positive values were observed between calcium and carbonate and between carbonate and magnesium, which also presented extremely low values of their ratio variances. The molar ratios $\mathrm{Ca} / \mathrm{CO}_{3}$ and $\mathrm{Mg} / \mathrm{CO}_{3}$ (0.9 and 0.1 respectively) agree with magnesian calcite deposits, which are characteristic of brackish and saline sediments (Stumm \& Morgan, 1981). The three components presented high negative covariances with clay elements, what indicates that calcium and magnesium were practically excluded from clay material.

The fourth association of elements can be distinguished only in C1. It is formed by phosphorus, iron and aluminium with high positive covariances and high negative values with carbonate elements. This group may be associated with the iron oxyhydroxide phase, because association between phosphorus and metals appeared only in C1 (two months after a complete mixing that allowed oxygenation of sediments) and was not observed in $\mathrm{C} 2$, collected after eight months of permanent anoxia (Fig. 5a). Iron oxyhydroxides have a strong capacity to adsorb phosphate (Lijklema, 1980; Brinkman, 1993), but under anoxic conditions redissolution of iron hydroxides makes the sediment ineffective for phosphorus trapping (Span et al., 1992; Lazzareti et al, 1992): phosphorus is released to the porewater and later to the water column, whereas iron remains in the sediment because of the precipitation of FeS.The high concentrations of phosphate in porewater observed in July $\left(250 \mu\right.$ mols. $\mathrm{I}^{-1}$ in July, 50 $\mu$ mols. $1^{-1}$ in December) also agreee with both, the decrease of phosphorus in the solid phase (see Table 1) and the change in the association of phosphorus with the other elements. In C2, sedi- 
Table 2. Variation matrix where A1-Fe etc., means the variance of natural logarithm of the ratio AlFe,etc. A: variances in core C1; B: variances in core $\mathrm{C} 2 ; \boldsymbol{C}$ : variances for the whole data set. Matriz de varianzas en la que Fe-Al etc., indica la varianza del logaritmo natural de la relación AlFe, etc. A: varianzas del core $C I ; B$ : varianzas en el core $C 2 ; C$ : varianzas de todo el conjunto de datos.

\begin{tabular}{|c|c|c|c|c|c|c|c|c|c|c|c|}
\hline A & $\mathrm{Fe}$ & Ti & $\mathbf{S i}$ & $\mathrm{Ca}$ & $\mathrm{Mg}$ & $\mathbf{P}$ & $\mathbf{K}$ & Mn & C. $\mathrm{CO}_{3}$ & C.C $\mathrm{C}_{\text {org }}$ & N.Ntot \\
\hline AI & 0.0237 & 0.0255 & 0.0382 & 0.1195 & 0.1559 & 0.1451 & 0.0117 & 0.2071 & 0.1411 & 0.2371 & 0.4020 \\
\hline $\mathrm{Fe}$ & & 0.0177 & 0.0135 & 0.0527 & 0.0755 & 0.1221 & 0.0284 & 0.1114 & 0.0602 & 0.1313 & 0.2477 \\
\hline $\mathrm{Ti}$ & & & 0.0268 & 0.0757 & 0.1068 & 0.1700 & 0.0246 & 0.1431 & 0.0930 & 0.1628 & 0.2917 \\
\hline $\mathrm{Si}$ & & & & 0.0252 & 0.0440 & 0.1643 & 0.0227 & 0.1229 & 0.0339 & 0.0976 & 0.2238 \\
\hline $\mathrm{Ca}$ & & & & & 0.0038 & 0.2243 & 0.0914 & 0.0906 & 0.0027 & 0.0403 & 0.1286 \\
\hline $\mathrm{Mg}$ & & & & & & 0.2431 & 0.1272 & 0.0827 & 0.0048 & 0.0281 & 0.1010 \\
\hline $\mathrm{P}$ & & & & & & & 0.1801 & 0.1767 & 0.2266 & 0.2609 & 0.3321 \\
\hline K & & & & & & & & 0.2056 & 0.1147 & 0.2069 & 0.3713 \\
\hline Mn & & & & & & & & & 0.0711 & 0.0710 & 0.0841 \\
\hline C. $\mathrm{CO}_{3}$ & & & & & & & & & & 0.1207 & 0.2190 \\
\hline C. $C_{\text {org }}$ & & & & & & & & & & & 0.0531 \\
\hline
\end{tabular}

\begin{tabular}{|c|c|c|c|c|c|c|c|c|c|c|c|}
\hline B & $\mathrm{Fe}$ & $\mathbf{T i}$ & $\mathbf{S i}$ & $\mathrm{Ca}$ & Mg & $\mathbf{P}$ & $\mathbf{K}$ & Mn & ${\mathrm{C} . \mathrm{CO}_{3}}_{3}$ & C.C $C_{\text {org }}$ & N.Ntot \\
\hline AI & 0.0267 & 0.0205 & 0.0445 & 0.1435 & 0.1659 & 0.2092 & 0.0014 & 0.1231 & 0.1611 & 0.2650 & 0.5144 \\
\hline $\mathrm{Fe}$ & & 0.0382 & 0.0208 & 0.0744 & 0.0853 & 0.1038 & 0.0193 & 0.0573 & 0.0824 & 0.1443 & 0.3395 \\
\hline $\mathrm{Ti}$ & & & 0.0410 & 0.1203 & 0.1447 & 0.2257 & 0.0226 & 0.1301 & 0.1339 & 0.2688 & 0.5432 \\
\hline $\mathrm{Si}$ & & & & $0.03 \mathrm{I} 5$ & 0.0435 & 0.0989 & 0.0364 & 0.0665 & 0.0385 & 0.1438 & 0.3739 \\
\hline $\mathrm{Ca}$ & & & & & 0.0023 & 0.0608 & 0.1263 & 0.0882 & 0.0016 & 0.0901 & 0.2842 \\
\hline $\mathrm{Mg}$ & & & & & & 0.0482 & 0.1463 & 0.0895 & 0.0022 & 0.0715 & 0.2467 \\
\hline $\mathrm{P}$ & & & & & & & 0.1815 & 0.0958 & 0.0460 & 0.0199 & 0.1138 \\
\hline $\mathrm{K}$ & & & & & & & & 0.1132 & 0.1421 & 0.2380 & 0.4725 \\
\hline $\mathrm{Mn}$ & & & & & & & & & 0.0869 & 0.1141 & 0.3007 \\
\hline C. $\mathrm{CO}_{3}$ & & & & & & & & & & 0.0771 & 0.2407 \\
\hline C.C org $_{\text {o }}$ & & & & & & & & & & & 0.0558 \\
\hline
\end{tabular}

\begin{tabular}{|c|c|c|c|c|c|c|c|c|c|c|c|}
\hline C & $\mathrm{Fe}$ & Ti & $\mathbf{S i}$ & $\mathrm{Ca}$ & $\mathrm{Mg}$ & $\mathbf{P}$ & $\mathbf{K}$ & Mn & C. $\mathrm{CO}_{3}$ & C.C org & N.Ntot \\
\hline AI & 0.0260 & 0.0233 & 0.0441 & 0.1395 & 0.1706 & 0.1879 & 0.0069 & 0.1664 & 0.1606 & 0.2517 & 0.4564 \\
\hline $\mathrm{Fe}$ & & 0.0289 & 0.0175 & 0.0670 & 0.0852 & 0.1334 & 0.0255 & 0.0856 & 0.0761 & 0.1412 & 0.2910 \\
\hline $\mathrm{Ti}$ & & & 0.0377 & 0.1074 & 0.1369 & 0.2066 & 0.0236 & 0.1371 & 0.1231 & 0.2150 & 0.4125 \\
\hline $\mathrm{Si}$ & & & & 0.0297 & 0.0459 & 0.1613 & 0.0331 & 0.0970 & 0.0382 & 0.1273 & 0.2947 \\
\hline $\mathrm{Ca}$ & & & & & 0.0032 & 0.1895 & 0.1181 & 0.0940 & 0.0023 & 0.0790 & 0.2048 \\
\hline $\mathrm{Mg}$ & & & & & & 0.1966 & 0.1480 & 0.0908 & 0.0036 & 0.0652 & 0.1733 \\
\hline $\mathbf{P}$ & & & & & & & 0.1915 & 0.1494 & 0.1837 & 0.1506 & 0.2522 \\
\hline $\mathrm{K}$ & & & & & & & & 0.1611 & 0.1403 & 0.2223 & 0.4212 \\
\hline $\mathrm{Mn}$ & & & & & & & & & 0.8130 & 0.1016 & 0.1891 \\
\hline C. $\mathrm{CO}_{3}$ & & & & & & & & & & 0.1262 & 0.2403 \\
\hline C.C & & & & & & & & & & & 0.0579 \\
\hline
\end{tabular}

ment phosphorus was clearly associated with $\mathrm{C}_{\text {org }}$ (Fig. 5b) showing high negative covariance with clay elements. In both cores iron was also associated with the clay elements with which it presented high covariance values. The molar ratio
$\mathrm{Fe} / \mathrm{Al}$ was around 0.30 , slightly higher than that reported for alumino-silicates (Belmans et al., 1993), what also indicate the existence of iron phases other than clay minerals. The vertical profile of $\mathrm{Fe} / \mathrm{Al}$ ratio showed a clear increase of the 
Table 3. Centred log-ratio covariance matrix (see text for explanation). A: Covariances in core C1; $\mathrm{B}$ : covariances in core $\mathrm{C} 2$; C: covariances for the whole data set. Matriz de covarianzas centradas de la relacidn logaritmica (ver texto para la explicacidn). A: Covarianzas en el core CI; B: covarianzas en el core C2; C: covarianzas para todo el conjunto de los datos.

\begin{tabular}{|c|c|c|c|c|c|c|c|c|c|c|c|}
\hline A & $\mathbf{K}$ & $\mathbf{T i}$ & $\mathbf{P}$ & Mn & $\mathbf{F e}$ & $\mathbf{S i}$ & $\mathrm{Ca}$ & $\mathrm{Mg}$ & $\mathrm{CO}_{3}$ & $\mathrm{C}_{\text {org }}$ & Ntot \\
\hline $\mathrm{Al}$ & 0.0910 & 0.0740 & 0.0852 & 0.0251 & 0.0636 & 0.0447 & -0.0080 & -0.0242 & -0.0155 & -0.0458 & -0.0887 \\
\hline K & & 0.0622 & 0.0544 & 0.0091 & 0.0488 & 0.0406 & -0.0054 & -0.0201 & -0.0143 & -0.0425 & -0.0848 \\
\hline $\mathrm{Ti}$ & & & 0.0501 & 0.0330 & 0.0448 & 0.0288 & -0.0067 & -0.0201 & -0.0112 & -0.0275 & -0.0523 \\
\hline $\mathrm{P}$ & & & & 0.0970 & 0.0641 & 0.0305 & -0.0108 & -0.0177 & -0.0103 & -0.0076 & 0.0008 \\
\hline $\mathrm{Mn}$ & & & & & 0.0344 & 0.0058 & -0.0075 & -0.0132 & 0.0039 & -0.0072 & 0.0300 \\
\hline $\mathrm{Fe}$ & & & & & & 0.0245 & -0.0059 & -0.0149 & -0.0076 & -0.0245 & -0.0404 \\
\hline $\mathrm{Si}$ & & & & & & & -0.0026 & -0.0094 & -0.0197 & -0.0197 & -0.0390 \\
\hline $\mathrm{Ca}$ & & & & & & & & 0.0022 & 0.0009 & 0.0017 & 0.0018 \\
\hline $\mathrm{Mg}$ & & & & & & & & & 0.0032 & 0.0118 & 0.0195 \\
\hline $\mathrm{CO}_{3}$ & & & & & & & & & & 0.0030 & 0.0138 \\
\hline $\mathrm{C}_{\text {org }}$ & & & & & & & & & & & 0.0678 \\
\hline
\end{tabular}

\begin{tabular}{|c|c|c|c|c|c|c|c|c|c|c|c|}
\hline B & $\mathbf{K}$ & $\mathbf{T i}$ & $\mathbf{P}$ & Mn & $\mathbf{F e}$ & $\mathbf{S i}$ & $\mathrm{Ca}$ & Mg & $\mathrm{CO}_{3}$ & $\mathrm{C}_{\text {org }}$ & Ntot \\
\hline $\mathrm{Al}$ & 0.1159 & 0.1057 & 0.0774 & 0.0502 & 0.0373 & -0.0129 & -0.0232 & -0.0181 & -0.0206 & -0.0309 & -0.0659 \\
\hline K & & 0,0959 & 0.0726 & 0.0458 & 0.0339 & -0.0124 & -0.0215 & -0.0167 & -0.0145 & -0.0252 & -0.0523 \\
\hline $\mathrm{Ti}$ & & & 0.0625 & 0.0434 & 0.0248 & -0.0092 & -0.0206 & -0.0143 & -0.0381 & -0.0437 & -0.0900 \\
\hline $\mathrm{Fe}$ & & & & 0.0292 & 0.0387 & -0.0097 & -0.0139 & -0.0114 & 0.0019 & -0.0017 & -0.0064 \\
\hline $\mathrm{Si}$ & & & & & 0.0161 & -0.0045 & -0.0093 & -0.0074 & -0.0132 & -0.0209 & -0.0424 \\
\hline $\mathrm{Mn}$ & & & & & & -0.0058 & -0.0049 & -0.0042 & 0.0175 & 0.0241 & 0.0257 \\
\hline $\mathrm{Ca}$ & & & & & & & 0.0023 & 0.0019 & -0.0032 & -0.0026 & -0.0049 \\
\hline $\mathrm{Mg}$ & & & & & & & & 0.0033 & 0.0052 & 0.0091 & 0.0168 \\
\hline $\mathrm{CO}_{3}$ & & & & & & & & & 0.0026 & 0.0050 & 0.0109 \\
\hline $\mathrm{P}^{-3}$ & & & & & & & & & & 0.0595 & 0.1133 \\
\hline $\mathrm{C}_{\text {org }}$ & & & & & & & & & & & 0.1528 \\
\hline
\end{tabular}

\begin{tabular}{|c|c|c|c|c|c|c|c|c|c|c|c|}
\hline C & $\mathbf{K}$ & $\mathbf{T i}$ & $\mathbf{P}$ & Mn & $\mathbf{F e}$ & $\mathbf{S i}$ & Ca & Mg & $\mathrm{CO}_{3}$ & $C_{\text {org }}$ & Ntot \\
\hline $\mathrm{AI}$ & 0.1064 & 0.0931 & 0.0718 & 0.0477 & 0.0097 & -0.0112 & -0.0248 & -0.0182 & 0.0496 & -0.0294 & -0.0726 \\
\hline $\mathrm{K}$ & & 0.0834 & 0.0624 & 0.0438 & 0.0058 & -0.0098 & -0.0227 & -0.0173 & 0.0382 & -0.0238 & -0.0640 \\
\hline $\mathrm{Ti}$ & & & 0.0559 & 0.0366 & 0.0117 & -0.0091 & -0.0218 & -0.0143 & 0.0256 & -0.0259 & -0.0644 \\
\hline $\mathrm{Fe}$ & & & & 0.0270 & 0.0202 & -0.0091 & -0.0152 & -0.0103 & 0.0433 & -0.0081 & -0.0218 \\
\hline $\mathbf{S i}$ & & & & & 0.0029 & -0.0038 & -0.0097 & -0.0073 & 0.0142 & -0.0175 & -0.0384 \\
\hline $\mathrm{Mn}$ & & & & & & -0.0047 & $-0.00 \mathrm{I5}$ & 0.0007 & 0.03 .59 & 0.0260 & 0.0482 \\
\hline $\mathrm{Ca}$ & & & & & & & 0.0026 & 0.0017 & -0.0101 & -0.0020 & -0.0019 \\
\hline $\mathrm{Mg}$ & & & & & & & & 0.0038 & -0.0113 & 0.0078 & 0.0168 \\
\hline $\mathrm{CO}_{3}$ & & & & & & & & & -0.0089 & 0.0010 & 0.0107 \\
\hline $\mathrm{P}^{3}$ & & & & & & & & & & 0.0441 & 0.0595 \\
\hline $\mathrm{C}_{\text {org }}$ & & & & & & & & & & & 0.1102 \\
\hline
\end{tabular}

quotient towards surface with a maximum at $6 / 8$ cm (Fig. 4), indicating a preferential accumulation of iron at this point.

Finally, manganese presented high variances of the ratios with all the other components, indicating that it was not clearly associated with any other phase in the sediments.

\section{Processes Controlling Sediment Composition}

Principal component analysis was used to identify the main factors that control chemical composition of the Es Cibollar sediments. Following Aitchinson (1986), principal component analysis was performed on the centred log-ratio data. 


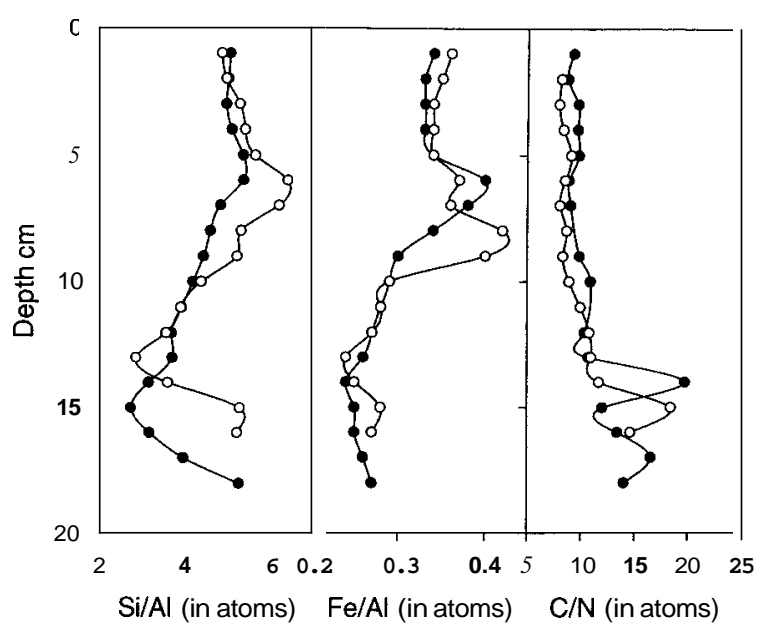

Figure 4. Vertical variation of the atomic ratio $\mathrm{Si} / \mathrm{Al}, \mathrm{Fe} / \mathrm{Al}$ and organic carbon/nitrogen. Full circles: December data; empty circles: July data. Variación vertical de los cocientes atdmicos Si/Al, Fe/Al y carbono orgánico/nitrógeno. Circulos negros: datos de Diciembre. Circulos blancos: datos de Julio

Because of the small number of samples in each core $(14 / 16)$, factor analysis was conduced on the whole set of data.

Factor analysis extracted two principal components that explained respectively $58.2 \%$ and $23.7 \%$ of total variance. Varimax rotated factor loadings are given in Table 4. For purposes of interpretation a "high" loading is defined as greater than 0.75 and a "moderate" loading as $0.40-0.75$. These division are arbitrary as no single method exists to define a significant loading. However, similar categories have been used by Puckett $\&$ Bricker, 1992, Votsinou-Taliadouri \& Varnavas (1995) and Evans et al (1996).

The first factor presented high positive loadings with the elements related to the clay fraction and negative loadings with carbonate elements. Total nitrogen also presented a moderate negative loading for this factor. Because of the high values for clay elements, the first component has been considered to be representative of the allogenic fraction of sediments, since clay minerals primarily reflect source lithologies (Jones \& Bowser, 1978). Thus, the negative loadings for carbonate elements can be interpreted as consequence of its autochthonous origin. Calcium car- bonate precipitation (both biological and chemical) is a common process in coastal systems and the ratio $\mathrm{Ca} / \mathrm{CO}_{3}$ and $\mathrm{Mg} / \mathrm{CO}_{3}(0.92$ and 0.09 in mols respectively) agreed with endogenous precipitation of rich-magnesium calcite in saline waters (Stumm \& Morgan, 1981). Finally, the moderate negative loading for nitrogen may also be explained in similar terms: the allochthonous organic matter is usually poor in nitrogen because of the high $\mathrm{C} / \mathrm{N}$ ratio in terrestrial vegetation and the rapid leaching of nitrogen through organic decomposition (Stumm \& Morgan,
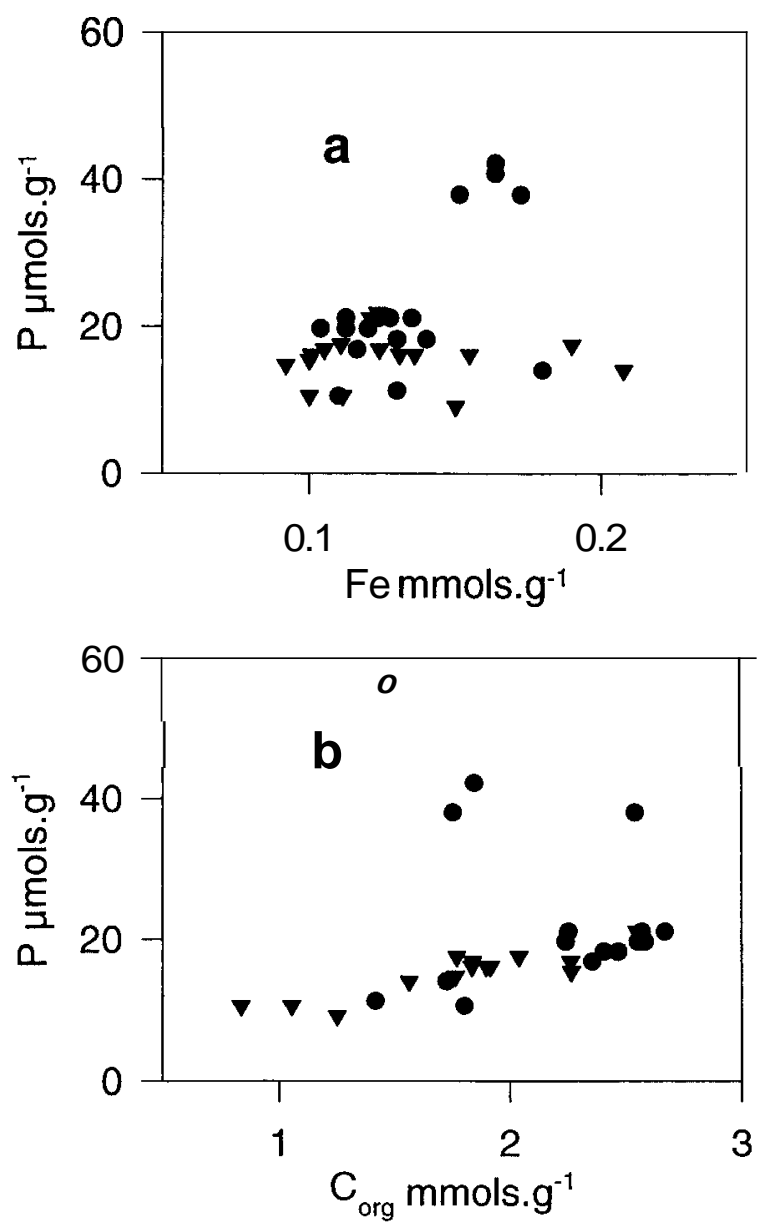

Figure 5. Relationships between phosphorus and iron (a) and organic carbon (b) in the two cores sampled. Circles: December data; triangles: July data. Relación entre la concentracidn de fósforo $y$ hierro (a)y fósforo y carbono orgánico $(b)$ en las dos épocas muestreadas. Circulos: datos de Diciembre. Triangulos: datos de Julio. 
1981; Santiago et al., 1994), so sedimentary nitrogen is usually of autochthonous origin, negative loading appearing for the first factor. Nevertheless, organic matter is modified in sediments by decomposing activity so only a moderate loading could be expected.

The second factor was characterized by high loadings for organic elements, carbon and nitrogen, moderate positive loading for phosphorus and manganese and moderate negative loadings for calcium. This second component has been interpreted as representative of the organic matter accumulation/decomposition. High concentrations of organic carbon, nitrogen and phosphorus (from organic origin) may be related to high rates of sedimentation of detritic materal rather than to low efficiency of anaerobic respiration. Several authors have established that loss of organic carbon is the same under aerobic and anaerobic conditions (Mackin \& Swider, 1989; Canfield 1989, Hansen \& Blackburn, 1991). High decomposition rate not only determine lower concentrations of organic elements, but also cause reduced conditions by exhaustion of electron acceptors (oxygen, nitrate and sulfate progressively), whicht in turn allow desorption of phosphate from oxihydroxide phases and solubilization of manganese (Stum and Morgan, 198I). High positive loading

Table 4. Varimax rotated factor loadings for the whole data set. Loadings lower than 0.4 have considered to be non-significant and have been omitted. Matriz rotada según el método varimax de los factores de carga para todo el conjunto de datos. Cargas inferiores a 0.4 se han considerado no significativas y han sido omitidas.

\begin{tabular}{lcc} 
& Factor $\mathbf{1}$ & Factor 2 \\
\hline $\mathbf{A I}$ & 0.986 & \\
$\mathrm{Fe}$ & 0.915 & \\
$\mathrm{Ti}$ & 0.918 & \\
$\mathrm{Si}$ & 0.946 & \\
$\mathrm{~K}$ & 0.973 & \\
$\mathrm{Mg}$ & -0.932 & \\
$\mathrm{CO}_{3}$ & -0.857 & -0.511 \\
$\mathrm{Ca}$ & -0.806 & 0.855 \\
$\mathrm{~N}_{\text {tot }}$ & -0.416 & 0.893 \\
$\mathrm{C}_{\text {org }}$ & & 0.748 \\
$\mathrm{P}_{\mathrm{Mn}}$ & & 0.605 \\
\hline
\end{tabular}

for carbon, nitrogen, but also phosphate and manganese thus reflected the sum of both processes. More difficult to explain is the negative loading observed for calcium. Organic matter decomposition may cause a redissolution of calcium carbonate through the associated drop in $\mathrm{pH}$ and, in this case, positive loadings for carbonate and calcium should appear, which did not occur. On the other hand, an intense sedimentation of organic matter could produce a "solid dilution" of the carbonate phase and, in this case, negative loadings should be expected not only for calcium, but also for carbonate and magnesium. Our interpretation of the behaviour of calcium is that it was related to the input of inland water by horizontal irrigation. Inland water presented a $\mathrm{Ca} / \mathrm{Mg}$ ratio higher than that of the marine water and it was rich in nitrate (Moyà, com. per.), that may be used as electron-acceptor for respiratory activity. At the depths at which inland water seeps into the lagoon an increase in decomposing activity (by supply of electron-acceptors for respiratory activity) and a relative enrichment of calcium in precipitated calcite (because of the higher $\mathrm{Ca} / \mathrm{Mg}$ ratio) should appear simultaneously, explaining the negative relationship between calcium and organic elements in the solid phase. However, the importance of horizontal irrigation as factor controlling sediment composition needs further investigation.

\section{Vertical Zonation}

Another basic goal of principal component analysis is classification of samples, based on the distances calculated for the reduced space defined by the the main components. These score values describe how of each core sample is related to the active process associated with the components. Figure 6 shows the position of the samples studied in the space defined by allochthonous input (Factor 1) and organic matter accumulation/decomposition (Factor 2). From the figure 6, three different layers may be distinguished for Es Cibollar sediments.

A: the deepest layer $(17$ to $18 \mathrm{~cm}$ in $\mathrm{C} 1 ; 14$ to $16 \mathrm{~cm}$ in $\mathrm{C} 2$ ). It corresponds to the original bed 


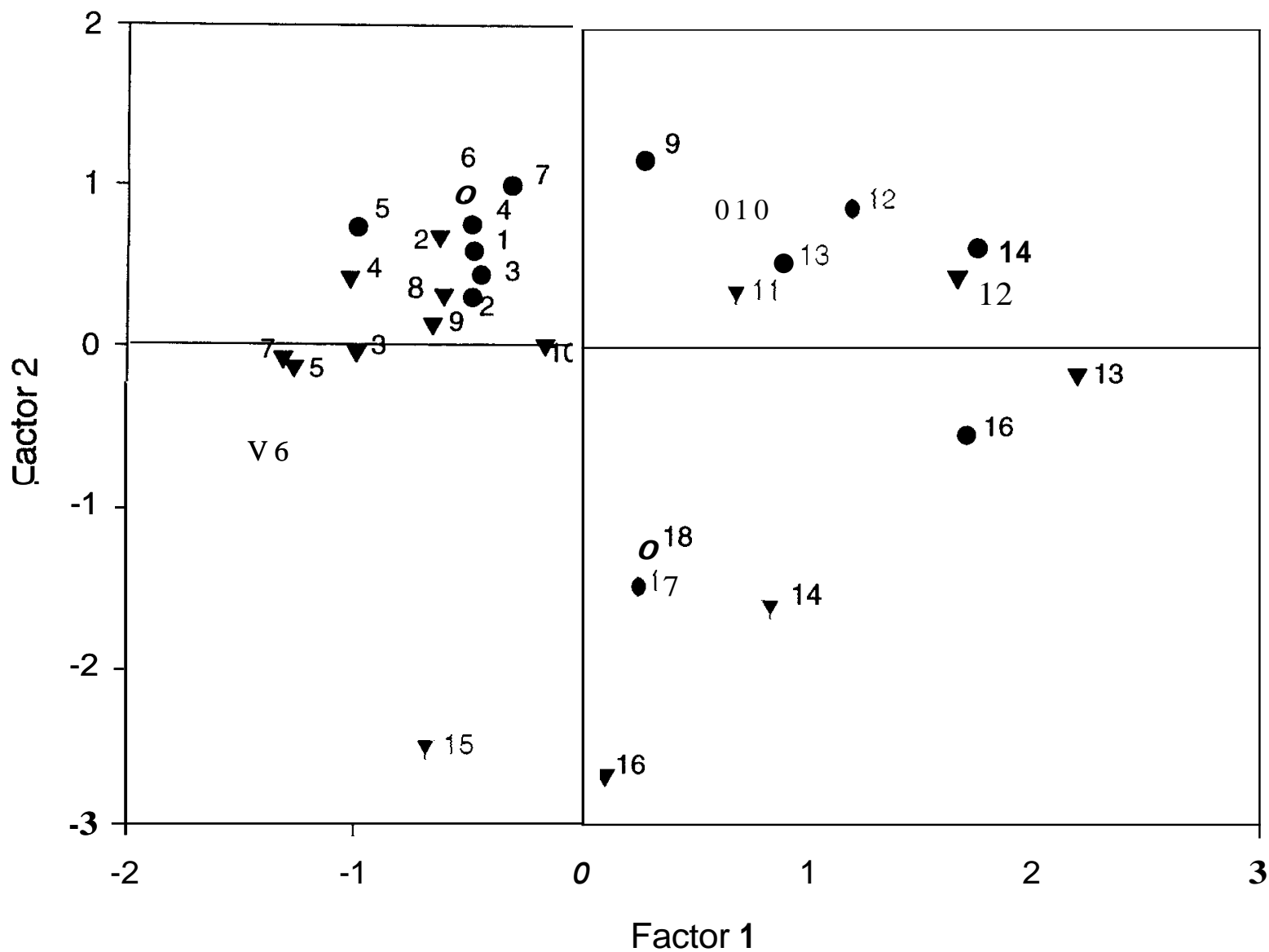

Figure 6. Position of the studied samples in the space defined by the two principal components. Numbers indicated the depth of the sample. Circles: December data; triangles: July data. Posicidn de las muestras estudiadas en el espacio definido por las dos componentes principales. Los números indican la profundidad de la muestra. Círculos: dutos de Diciembre. Triangulos: dutos de Julio.

of the lagoon, presenting a very different texture with abundance of coarse materials. It was characterized by the low content in organic matter and a high $\mathrm{Si} / \mathrm{Al}$ ratio caused by the high percentage of quartz sands.

B: the clay accumulation layer ( 9 to $16 \mathrm{~cm}$ in $\mathrm{C} 1 ; 11$ to $13 \mathrm{~cm}$ in $\mathrm{C} 2$ ). It corresponds to the layer with the highest concentrations of clay elements and with a molar ratio $\mathrm{Fe} / \mathrm{Al}$ close to that observed in alumino-silicates. Clay elements decreased towards the surface of the layer, whereas organic matter and the $\mathrm{Si} / \mathrm{Al}$ ratio tended to increase parallely. A progressive decrease in the allochthonous input of particulate matter since the formation of the lagoon after dredging is con- sistent with the observed variations. Because of its simultaneous variation with organic matter accumulation, the increase in the $\mathrm{Si} / \mathrm{Al}$ ratio seems to be due to the accumulation of diatom detritus rather than to an increase in the percentage of quartz sands.

$\mathrm{C}$ : the endogenous layer ( 0 to $8 \mathrm{~cm}$ in $\mathrm{C} 1 ; 0$ to $10 \mathrm{~cm}$ in $\mathrm{C} 2$ ). It corresponds to the most recent sediments and was characterized by the lowest concentrations of clay elements, which also were very homogeneous. A maximum value in the $\mathrm{Fe} / \mathrm{Al}$ ratio was observed at the transition with layer B. Whereas both cores presented similar features with respect to Factor 1, clear differences appeared between them with respect organic mat- 
ter accumulation. In $\mathrm{C} 1$, this was higher and tended to increase with depth, but in $\mathrm{C} 2$ a maximum was observed at its surface and the minimum values appeared at the middle of the layer $(6 \mathrm{~cm})$. The hypothesis of horizontal irrigation as an important factor controlling organic matter decomposition (by providing electron-acceptors for respiratory activity) may also explain these differences. The level of inland groundwater decreases notably in summer (when C2 was collected) because of the increased water demand for agricultural or domestic uses. So, whereas in winter inland water came through horizontal irrigation at the surface of sediments, in summer it arrived only at $6 \mathrm{~cm}$ depth causing a maximum decomposing activity at this depth, and, in turn, the minimum in organic matter accumulation observed.

In conclusion, the geochemical composition of the Es Cibollar sediment was mainly related to the relative contribution of allogenic and endogenic settled matter. The marked differences in the vertical profiles of the major constituents, $\mathrm{Al}$, $\mathrm{Fe}, \mathrm{Si}, \mathrm{K}, \mathrm{Ca}, \mathrm{Mg}$ and carbonate were consistent with changes in the water circulation over time, whereas nutrient elements, such as organic carbon, nitrogen and phosphorus, were dependent on the balance between organic matter accumulation and decomposition. The geochemical data also suggested that the input of inland water by horizontal irrigation and the changes in groundwater level were an important factor that partially determinated the vertical distribution of calcium and nutrient elements. Finally, long periods of anoxia only produced a clear modification in the concentration of phosphorus, which changed from iron- phosphorus association after a mixing event to organic carbon/phosphorus association after eight months of permanent anoxia.

\section{ACKNOWLEDGMENTS}

The authors are very grateful to the staff of the "Parc Natural de S'Albufera de Mallorca" and to the group of G. Moyà and to M.Vidal and J.A. Morgui for their help during the field work. Bulk analysis were performed in the "Serveis Cientific-
Tecnics de l'Universitat de Barcelona". We also thank R. Rycroft for improving the language of this text. This research has been supported by the CICYT project AMB92-0716-C02-02.

\section{REFERENCES}

AITCHINSON, J. 1986. The statistical analysis of compositional data. London: Chapman and Hall.

BELMANS, F., R. GRIEKEN \& L.. BRUGMANN. 1993. Geochemical characterization of recent sediments in the Baltic Sea by bulk and electron microprobe analysis. Mar: Chem., 42: 223-236.

BONANNI, P., R. CAPRIOLI, E. GHIARA, C. MIGNUZZI, C. ORLANDI, G. PAGANIN \& A. MONTI. 1992. Sediment and interstital water chemistry of the Ortebello lagoon Grosseto, Italy.; nutrient diffusion across the water-sediment interface. $\mathrm{Hy}$ drobiologia, 235/236: 553-68.

BRINKMAN, A.G. 1993. A double-layer model for ion adsorption onto metal oxides, applied to experimental data and to natural sediments of Lake Veluwe, The Netherlands. Hydrobiologia, 253: 31-45.

CANFIELD, E.D. 1989. Sulphate reduction and oxic respiration in marine sediments: implications for organic carbon preservation in euxinic environments. Deep Sea Res., 36: 121-138.

EVANS, C.D., T.D. DAVIES, P.J. WIGINGTON, M. TRANTER \& W.A. KRESTER. 1996. Use of factor analysis to investigate processes controlling the chemical composition of four streams in the Adirondack Mountains, New York. J. Hydrology, 185: 297-316.

FORSTNER, U. 1989. Contaminated sediments. Lecture Notes in Earth Sciences 21. Berlin: Springer Verlag.

HANSEN, L.S.\&T.H. BLACKBURN. 1991. Aerobic and anaerobic mineralization of organic material in marine sediment microcosms. Mar: Ecol. Prog. Ser:, 75:283-291.

JONES, B.F.\& C.J. BOWSER. 1978. The mineralogy and related chemistry of lake sediments. In: Lakes Chemistry, Geology, Physics. A. Lerman (ed.): 179235. Springer Verlag, New York.

LAZZARETTI, M.A., K.W. HANSELMANN, H. BRANDL, D. SPAN \& R. BACHOFEN. 1992. The role of sediments in the phosphorus cycle in Lake Lugano. 11. Seasonal and spatial variability of microbiological processes at hte sediment-water interface. Aquat. Sci., 54: 285-299. 
LIJKLEMA, L. 1980. Interaction of ortophosphate with iron III and aluminum hydroxides. Environm. Sci. Technol., 14, 537-541.

LÓPEZ, P., J.A. MORGUÍ, M. VIDAL \& X. LLUCH. 2000. Porewater composition and alkalinity balance in sediments of a meromictic coastal lagoon (Cibollar, Majorca, Spain). Verh. Internat. Verein Limnol. (in press).

MACKIN, J.E.,\& K.T. SWIDER. 1989. Organic matter decomposition pathway and oxygen consumption in coastal marine sediments. J. Mar Res., 47: 681-716.

MARTÍNEZ-TABERNER, A., G, MOYA, G. RAMON \& V. FORTEZA .1990. Limnological criteria for the rehabilitation of a coastal marsh. The Albufera of Majorca, Balearic Islands. Ambio, 19:21-27.

MOYÀ, G., G. RAMÓN, A. MARTÍNEZ-TABERNER, V. FORTEZA, C. PICO, C. PONSELL, R. ROSSELLO \& M.A. SOBERATS. 1987. Limnology of a meromictic coastal lagoon. L'Estany del Cibollar (Majorca, Balearic Islands). Limnética, 3: 255-262.

MUSIKAS, N . \& G. VANTIGHEM. 1977. For a better utilization of XRF in cement works. Rev. Mat. Constr, 706: 135-144.

PRINCIPI, C., R. BAUDO \& H. MUNTAU. 1994. Spatial and temporal heterogeneity of Lake Lugano sediment composition. Aquat. Sci., 56: 243-262.

PUCKETT, L.J. \& O.P. BRICKER. 1992. Factors controlling the major ion chemistry of streams in the Blue Ridge and Valley and Ridge physiographic provinces of Virginia and Maryland. Hydrol. Processes, 6: 79-98.

ROLLINSON, H. 1993. Using geochemical data. Evaluution, presentation, interpretation. Longman Scientific and Technical. Essex

SANTIAGO, S., R.L. THOMAS, G. LARBAIGT, C. CORVI, D. ROSSEL, J. TARRADELLAS, D.J. GREGOR, L. MCCARTHY \& P.J. VERNET. 1994. Nutrient, heavy metal and organic pollutant composition of suspended and bed sediments in the Rhone River. Aquat. Sci., 56: 220-242.

SPAN, D., J. DOMINIK, M.A. LAZZARETTI \& J.P. VERNET. 1992. The role of sediments in the phosphorus cycle in Lake Lugano. I Geochemical approach. Aquat. Sci., 54: 277-284.

STRIEBEL, T., W. SCHAFER \& S. PEIFFER. 1991. How does landfill leachate affect the chemical processes in a lake system downgradient from a landfill site?. Aquat. Sci., 53: 346-366.

STUMM, W. \& J.J. MORGAN. 1981. Aquatic chemistry. J. Wiley \& Sons. NY.

VAN ALSENOY, V., P. BERNARD \& R. GRIEKEN. 1993. Elemental concentrations and heavy metal pollution in sediments and suspended matter from the Belgian North Sea and the Scheldt estuary. Sci. Tot. Environ., 133: 153-181.

VOUTSINOU-TALIADOURI, F. \& S.P. VARNAVAS. 1995. Geochemical and sedimentological patterns in the Thermaikos Gulf, North-west Aegean Sea, formed from a multisource of elements. Estuar Coast Shelf Sci., 40: 295-320. 